\title{
Use of Nonhuman Primate Models to Develop Mucosal AIDS Vaccines
}

\author{
Meritxell Genescà • Christopher J. Miller
}

Published online: 6 February 2010

(C) The Author(s) 2010. This article is published with open access at Springerlink.com

\begin{abstract}
The HIV vaccines tested in the halted Step efficacy trial and the modestly successful phase 3 RV144 trial were designed to elicit strong systemic immune responses; therefore, strategies to direct immune responses into mucosal sites should be tested in an effort to improve AIDS vaccine efficacy. However, as increased $\mathrm{CD}^{+} \mathrm{T}$-cell activation and recruitment to mucosal sites have the potential to enhance HIV transmission, mucosal immune responses to HIV vaccines should primarily consist of effector $\mathrm{CD}^{+} \mathrm{T}$ cells and plasma cells. Controlling the level of mucosal T-cell activation may be a critical factor in developing an effective mucosal AIDS vaccine. Immunization routes and adjuvants that can boost antiviral immunity in mucosal surfaces offer a reasonable opportunity to improve AIDS vaccine efficacy. Nonhuman primate models offer the best system for preclinical evaluation of these approaches.
\end{abstract}

Keywords HIV · Female genital tract · Immune activation · SIV

\section{Introduction}

The recent inability to complete the efficacy trial of an AIDS vaccine designed to elicit systemic T-cell responses [1-3] and the modest success in a human phase 3 trial of a

\author{
M. Genescà $\cdot$ C. J. Miller $(\square)$ \\ Center for Comparative Medicine, California National Primate \\ Research Center, University of California, Davis, \\ One Shields Avenue, \\ Davis, CA 95616, USA \\ e-mail: cjmiller@ucdavis.edu \\ M. Genescà \\ e-mail: mgenesca@primate.ucdavis.edu
}

second AIDS vaccine designed to elicit both systemic antiviral T-cell and antibody responses [4••] highlight the need for AIDS vaccines that induce antiviral immunity at mucosal surfaces that are the portal of entry for HIV. The mucosal immune system represents a highly compartmentalized immunological system that in many ways functions independently from the systemic immune system, although the systems do interact. The mucosal immune system is a specialized subset of lymphoid tissues and cells that preferentially reside within the wide variety of mucosal surfaces [5-7]. Along with the skin, these mucosal surfaces form the primary barrier between pathogens and the vertebrate host. Thus, the mucosal immune system is the first line of immunologic recognition and defense against the vast majority of microbial pathogens, including HIV. As with the systemic immune system, distinguishing self from nonself antigens is a critical feature of the mucosal immune system. However, a further challenge exists at mucosal surfaces, as they are populated with a large number of beneficial microorganisms. Thus, to maintain a normal mucosal flora, it is critical that the mucosal system is able to promote immune recognition of pathogens and maintain immune tolerance to commensal organisms [5-7].

The nature of the antigen, the specific antigen-presenting cells (APCs) involved, and the presence of inflammation in the tissue shape mucosal immune responses. With most antigens (eg, food proteins), the "default" pathway for mucosal dendritic cells (DCs) and other APCs generates T helper $2\left(\mathrm{~T}_{\mathrm{H}} 2\right)$ and regulatory T-cell responses that result in active suppression of systemic immunity or "oral tolerance" to food antigens [6]. Pathogens are recognized by mucosal APCs detecting pathogen-associated molecular patterns that bind to Toll-like receptors (TLRs), initiating innate immune and inflammatory responses. Proinflammatory conditions favor the development of stronger and broader immune 
responses promoting strong humoral and cellular immune responses [6]. Although it had been widely assumed that the commensal microbes were not recognized by the TLRs of mucosal APCs, microbial commensals are indeed recognized by TLRs under normal conditions, and this helps maintain epithelial homeostasis in the gut [6].

$\mathrm{B}$ and $\mathrm{T}$ cells, sensitized to antigen in mucosal inductive sites, leave the site of antigen presentation in the mucosa, move through the lymphatics to enter the blood to recirculate and re-enter mucosal tissues. The majority of these cells reenter the mucosa of origin, where they differentiate into memory or effector lymphocytes [5, 6]. The anatomic localization of mucosal lymphocytes is determined by expression of homing receptors (integrins) on their surface and complementary mucosal "addressins" on vascular endothelial cells $[5,6]$. Additionally, mucosal DCs influence the homing properties of mucosal $\mathrm{T}$ cells. Intestinal DCs produce retinoic acid, which increases the expression of the mucosal-homing receptor $\alpha 4 \beta 7$ and CCR9, the receptor for the gut-associated chemokine CCL25 $[5,6]$.

Taken together, these observations may explain the somewhat archaic notion of a "common mucosal immune system" $[5,6]$. Although early studies in mice suggested that the mucosal surfaces share a common set of mucosal lymphocytes and that immune responses induced at one site disseminate to all mucosal surfaces, the common mucosal immune system is more restricted than previously thought $[5,6]$. In humans, immunization studies with cholera toxin B subunit by different mucosal routes have clearly shown that the strongest response takes place at the immunized mucosa, with weaker responses at anatomically adjacent mucosal sites [5]. The differential expression of chemokines, integrins, and cytokines among mucosal tissues may explain the linkage between some mucosal inductive sites and particular distal effector sites (eg, the nose and female genital tract) [5].

\section{Mucosal HIV Transmission}

HIV is transmitted primarily by sexual contact, and the female genital tract, male genital tract, and rectum are the anatomic sites of virus transmission [8]. Nonhuman primate (NHP) models have been critical for understanding how the virus enters these mucosal surfaces, infects target cells, and disseminates from mucosal surfaces [9, 10]. HIV and simian immunodeficiency virus (SIV) rapidly penetrate the mucus covering the epithelial surface of the vagina and ectocervix and infect intraepithelial dendritic Langerhans cells and $\mathrm{CD}^{+} \mathrm{T}$ cells in the epithelium and lamina propria [11]. These infected cells enter draining lymphatics and can be found in the lymph nodes of the genital tract 18 to $24 \mathrm{~h}$ after exposure [11]. However, there is a little detectable viral replication in tissues until 5 days after infection, when there are simultaneous and dramatic increases in viral replication and innate antiviral immune responses (Type 1 interferon expression) in all tissues [9, 12]. Further, recent studies have conclusively demonstrated that immediately after mucosal transmission, many systemic HIV and many systemic SIV infections are established by a very limited number ( 1 or 2$)$ of viral envelope glycoprotein variants $[13,14 \bullet]$. Thus, vaccine-induced immune responses may only need to prevent infection or replication of a small number of virions transmitted during an exposure. Importantly, although the virus that establishes the systemic infection is more fit than chronic phase virus, acute phase virus is extremely sensitive to neutralization by chronic phase plasma, suggesting that transmitted virus could be similarly sensitive to vaccine-induced antibody responses [15]. Thus, there is a period between mucosal transmission and the onset of massive viral replication at day 5 postinfection that may provide an opportunity for vaccine-induced immune responses to limit or even eliminate a nascent HIV infection established by a limited number of viral variants before an infection becomes established in systemic lymphoid tissues.

\section{Engaging the Mucosal Immune System to Prevent HIV Transmission}

Vaccine-elicited antiviral effector mechanisms of the mucosal immune system have the potential to provide three layers of protection from mucosal-transmitted pathogens, such as HIV: 1) dimeric secretory $\operatorname{IgA}$ and monomeric $\operatorname{IgG}$ and $\operatorname{IgA}$ in mucosal secretions can neutralize virions in the lumen prior to binding to target cells; 2) dimeric IgA can neutralize virions inside epithelial cells, and monomeric $\operatorname{IgG}$ and $\operatorname{IgA}$ can neutralize virions in the lamina propria; and, 3) virus-infected cells in the mucosa can be killed by mucosal cytotoxic $\mathrm{T}$ cells and by virus-specific IgG mediating antibody-dependent cellmediated cytotoxicity. If any invading virus should overcome these mucosal immune effector mechanisms, then the vaccineelicited systemic immune responses provide a final opportunity to eliminate HIV infection during the dissemination phase of infection. However, once an HIV infection becomes established in systemic lymphoid tissues, the best outcome that can be expected is enhanced immune control of viral replication.

To generate mucosal immune responses to HIV vaccines, two general strategies are available. Adjuvants can be used to stimulate the mucosal immune system, and specific routes of immunization can be used to direct immune responses toward specific mucosal surfaces. Mucosal immunization strategies, using either novel adjuvants codelivered with antigens or replication-defective viral vectors, represent an important next step in the development of improved AIDS vaccines. In fact, it seems likely 
that the efficacy of the vaccines tested in the RV144 and Step HIV vaccine trials could be improved by incorporating one or both of these strategies to induce antiviral immunity of mucosal surfaces. NHPs are critical in the effort to develop these strategies, as they are the only species that express the appropriate mucosal $\mathrm{T}$-cell homing receptors and vascular addressins for modeling human mucosal immune responses to vaccines.

\section{Mucosal Challenge Models for AIDS Vaccines}

A number of challenge models exist for assessing the protective potential of candidate AIDS vaccines, including NHP models using either SIV or laboratory-engineered chimeric SIV/HIV (SHIV) viruses. Although the chimeric SHIVs do not adequately reproduce AIDS pathogenesis and are not adequate to assess the ability of a candidate vaccine to alter disease progression, they are adequate to determine if a vaccine increases resistance to acquiring infection. The SIV models are excellent models of AIDS pathogenesis and can be used to assess the effect of vaccination on both resistance to acquiring infection and the rate of disease progression in immunized animals that become infected. Mucosal SIV challenge faithfully reproduces the key features of mucosal HIV transmission, including the transmission of a few variants from complex quasispecies of viral variants $[13,14 \cdot]$. In addition, NHP models can employ either a repeated low-dose virus challenge system or a single high-dose challenge system to meet the specific objectives of the experiment. NHP SHIV models of mucosal HIV transmission have been used to demonstrate that passive transfer of neutralizing monoclonal antibodies can prevent virus transmission [16], providing support for the concept that vaccine-elicited antibody responses can prevent transmission. Recently, a small animal model of HIV transmission was developed by transplanting human bone marrow, liver, and thymus (BLT) into severe combined immunodeficient mice [17]. Consequently, human APCs and lymphocytes populate the mucosal surfaces, and the model can be used to assess some strategies to prevent vaginal HIV transmission [18]. Further, once infected, the BLT mice generate humoral and cellular HIV-specific immune responses [19]. However, because TLR ligands are expressed on a different set of murine cells compared with human cells, it will be difficult to evaluate the utility of vaccines and adjuvants that elicit innate immunity in the BLT mouse. In addition, the existence of a common mucosal immune system in mice but not in humans is due to fundamental differences in the distribution of vascular addressins in mice and humans. Finally, murine mucosal immune responses do not reflect mucosal immune responses in NHPs or humans [6].

\section{Review of NHP Mucosal AIDS Vaccine Studies}

Although studying mucosal immunity is technically challenging due to difficulty in obtaining samples of sufficient quality and quantity for analysis, the need to improve the relatively low efficacy of the systemic AIDS vaccines currently in development demands a focus on eliciting mucosal immune responses through vaccination. Thus, there is a renewed effort to study mucosal immunology in preclinical studies of AIDS vaccines. The remainder of this review summarizes some recently published NHP studies using a mucosal route of virus challenge. The decision to focus primarily on the results of mucosal challenge studies is based on the fact that correlates of protection against HIV are unknown and thus, immunogenicity studies provide little insight into the protective potential of the candidate HIV vaccines [20]. Only studies with mucosal virus challenge provide an opportunity to assess the potential immune correlates of protection from mucosal challenge. In fact, NHP mucosal challenge studies [21] predicted the lack of immunogenicity and partial efficacy seen in the RV144 phase 3 trial of an ALVAC (recombinant canarypox vector)based HIV vaccine in Thailand [4••]. Critically, these preclinical studies of ALVAC-based vaccines studies used an appropriate NHP model and repeated low-dose mucosal challenge with highly pathogenic SIVmac251. Clearly, a similar approach to preclinical evaluation of HIV candidate vaccines should be used going forward.

Considerable literature documents the efforts of numerous investigators to elicit anti-SIV/SHIV mucosal immunity in NHP models. NHP have been immunized with recombinant SIV proteins or peptides, live-attenuated SIV or SHIV, viral or bacterial vectors encoding SIV genes, and DNA vaccines; this literature up to 2004 was summarized in the introduction of an article by Yoshino et al. [22]. An excellent review of more recent NHP mucosal AIDS vaccine studies was published earlier this year [23••]. In this article, we focus on some of the NHP AIDS vaccine studies with mucosal virus challenges published from 2007 to 2009 , which are summarized in Tables 1 and 2. Of the 12 articles using mucosal immunization routes, animals were immunized by the intranasal (IN) route in five articles, by the tonsillar route in four, by the intratracheal route in two, and by the rectal route in one (Table 1). Further, two articles used what was described as oral immunization, but the immunization actually consisted of placing enteric-coated capsules containing live Ad5 vectors into the stomach using gastric feeding tube (Table 1). Although IN immunization has been studied extensively, it is unlikely to ever be used clinically, as IN immunization in humans is rarely associated with onset of Bell's Palsy [6]. Of the nine articles using systemic immunization routes, the animals were immunized by the intramuscular route in six articles, by 
Table 1 Summary of recent (2007-2009) prophylactic AIDS vaccine studies employing mucosal immunization and mucosal virus challenge in NHP models ${ }^{\mathrm{a}}$

\begin{tabular}{|c|c|c|c|c|c|}
\hline Study & Vaccine & Vaccine route & $\begin{array}{l}\text { Challenge/ } \\
\text { route }\end{array}$ & Level of protection & Immune correlates \\
\hline $\begin{array}{l}\text { Vagenas et al. } \\
\text { [25] }\end{array}$ & AT-2 SIV + CpG-C & $\begin{array}{l}\text { Palatine/lingual } \\
\text { tonsils }\end{array}$ & $\begin{array}{l}\text { SIVmac239/ } \\
\text { IR }\end{array}$ & $\begin{array}{l}\text { Lower frequency of } \\
\text { infection; lower peak } \\
\text { plasma vRNA levels }\end{array}$ & $\begin{array}{l}\text { Antiviral } \mathrm{Ab} \text { in rectal } \\
\text { secretions }\end{array}$ \\
\hline Copeland [34] & $\begin{array}{l}\text { Prime SIV + IL-2 + IL-15 } \\
\text { DNA/boost SIV-MVA }\end{array}$ & IN or IM & $\begin{array}{l}\text { SIVmac251/ } \\
\text { IR }\end{array}$ & $\begin{array}{l}\text { CD4 T-cell } \\
\text { preservation and } \\
\text { delayed disease }\end{array}$ & $\begin{array}{l}\text { Systemic and colorectal } \\
\text { T-cell responses }\end{array}$ \\
\hline $\begin{array}{l}\text { Manrique } \\
\text { et al. [35] }\end{array}$ & $\begin{array}{l}\text { Prime multigenic DNA/ } \\
\text { boost MVA adjuvanted by } \\
\text { IL-12 DNA }\end{array}$ & $\begin{array}{l}\mathrm{IN} / \mathrm{IN} ; \mathrm{IM}+\mathrm{IN} / \mathrm{IM} \\
+\mathrm{IN} \text { or IM/IN }\end{array}$ & $\begin{array}{l}\text { SHIV89.6P/ } \\
\text { IR }\end{array}$ & $\begin{array}{l}\text { Lower peak/set point } \\
\text { plasma vRNA } \\
\text { levels; no AIDS } \\
\text { progression }\end{array}$ & $\begin{array}{l}\text { SHIV-specific T-cell } \\
\text { responses in blood }\end{array}$ \\
\hline $\begin{array}{l}\text { Falkensammer } \\
\text { et al. [36] }\end{array}$ & $\begin{array}{l}\text { SCIV/-SIV genes / Ad5-SIV } \\
\text { or SCIV-MULV env boost }\end{array}$ & Tonsils & $\begin{array}{l}\text { SIVmac239/ } \\
\text { tonsil }\end{array}$ & $\begin{array}{l}\text { Lower peak/set point } \\
\text { plasma vRNA levels }\end{array}$ & $\begin{array}{l}\text { Neutralizing } \mathrm{Ab} \text {; } \\
\text { complement } \mathrm{C} 3 \text {-deposition } \\
\text { on viral particles in plasma }\end{array}$ \\
\hline $\begin{array}{l}\text { Stahl-Hennig } \\
\text { et al. [37] }\end{array}$ & $\begin{array}{l}\text { Prime-boost regimen of } \\
\text { SCIV and adenoviral } \\
\text { vector vaccines }\end{array}$ & Tonsils & $\begin{array}{l}\text { SIVmac239/ } \\
\text { tonsil }\end{array}$ & $\begin{array}{l}\text { lower plasma vRNA } \\
\text { levels }\end{array}$ & $\begin{array}{l}\text { Strong } \mathrm{T} \text { cell and antibody } \\
\text { responses in blood }\end{array}$ \\
\hline $\begin{array}{l}\text { Bogers et al. } \\
{[38]}\end{array}$ & $\begin{array}{l}\text { Prime Ad5hr-HIV-1 (89.6p) } \\
\text { env/boost heterologous } \\
\text { Env protein or alphavirus } \\
\text { replicons }\end{array}$ & $\mathrm{IN}+\mathrm{IT} / \mathrm{IM}$ & $\begin{array}{l}\text { SHIV }_{\text {SF162p } 4} / \\
\text { IR }\end{array}$ & $\begin{array}{l}\text { Lower plasma vRNA } \\
\text { levels }\end{array}$ & $\begin{array}{l}\text { Titer of neutralizing } \\
\text { antibodies in sera }\end{array}$ \\
\hline $\begin{array}{l}\text { Hidajat et al. } \\
\text { [39] }\end{array}$ & $\begin{array}{l}\text { Prime Ad5hr-SIV with } \\
\text { env-gag- neflboost SIV } \\
\text { gp120 protein } \\
\text { (MPL-SE adjuvant) }\end{array}$ & $\begin{array}{l}\text { Oral (tablets }+ \\
\text { stomach tube })+ \\
\text { oral or IN }+ \text { oral/ } \\
\text { IM+ IM }\end{array}$ & $\begin{array}{l}\text { SIVmac251/ } \\
\text { IR }\end{array}$ & $\begin{array}{l}\text { Lower peak plasma } \\
\text { vRNA levels }\end{array}$ & $\begin{array}{l}\text { ADCVI activity and } \\
\text { transcytosis inhibition } \\
\text { activity in plasma }\end{array}$ \\
\hline $\begin{array}{l}\text { Demberg } \\
\text { et al. [40] }\end{array}$ & $\begin{array}{l}\text { Prime Ad5hr-SIV DNA } \pm \\
\text { IL-12 or IL-15/boost with } \\
\text { SIV gp140 + SIV nef } \\
\text { protein }\end{array}$ & $\mathrm{IM}+\mathrm{IT} / \mathrm{IM}$ & $\begin{array}{l}\text { SIVmac251/ } \\
\text { IR }\end{array}$ & No protection & None \\
\hline $\begin{array}{l}\text { Zhou et al. } \\
\text { [41] }\end{array}$ & $\begin{array}{l}\text { Prime Ad5 with SIV env/rev, } \\
\text { gag, and nef genes/boost } \\
\text { with SIV gp120 protein }\end{array}$ & $\begin{array}{l}\text { Oral }(\text { tablets }+ \\
\text { stomach tube })+ \\
\text { oral or IN }+ \text { oral/ } \\
\text { IM }+ \text { IM }\end{array}$ & $\begin{array}{l}\text { SIVmac251/ } \\
\text { IR }\end{array}$ & $\begin{array}{l}\text { Lower peak/setpoint } \\
\text { plasma vRNA levels }\end{array}$ & $\begin{array}{l}\mathrm{T} \text { cell responses to Gag and } \\
\text { Nef }\end{array}$ \\
\hline $\begin{array}{r}\text { Stolte-Leeb } \\
\text { et al. [42] }\end{array}$ & $\begin{array}{l}\text { Prime multigenic DNA/ } \\
\text { boost MVA }\end{array}$ & $\begin{array}{l}\text { ID/IM-ID + IM-ID } \\
\text { or IM-ID + } \\
\text { palatine tonsils }\end{array}$ & $\begin{array}{l}\text { SHIV89.6P/ } \\
\text { IR }\end{array}$ & $\begin{array}{l}\text { Lower peak/setpoint } \\
\text { plasma vRNA } \\
\text { levels; CD4 }{ }^{+} \text {T-cell } \\
\text { preservation }\end{array}$ & $\begin{array}{l}\text { None (better protection from } \\
\text { mucosal and systemic than } \\
\text { systemic vaccination } \\
\text { alone) }\end{array}$ \\
\hline $\begin{array}{l}\text { Barnett et al. } \\
{[26]}\end{array}$ & $\begin{array}{l}\text { HIV-1 SF162 envelope } \\
\text { protein vaccine }\end{array}$ & $\mathrm{IM} / \mathrm{IM}$ or IM/IN & $\begin{array}{l}\text { SHIV }_{\text {SF162p } 4} / \\
\text { IVAG }\end{array}$ & $\begin{array}{l}\text { Protected from } \\
\text { infection }\end{array}$ & $\begin{array}{l}\text { Serum-neutralizing } \\
\text { antibodies }\end{array}$ \\
\hline $\begin{array}{l}\text { Wang et al. } \\
\text { [24] }\end{array}$ & $\begin{array}{l}\text { HSP70 + SIVgp120 + } \\
\text { SIVp27 + CCR5; HSP70 } \\
\text { + SIVgp120 + SIVp27; } \\
\text { HSP70 + CCR5 }\end{array}$ & Rectal & $\begin{array}{l}\text { SIVmac251/ } \\
\text { IR }\end{array}$ & $\begin{array}{l}6 / 15 \text { protected from } \\
\text { infection }\end{array}$ & $\begin{array}{l}\text { Increased } \mathrm{A} 3 \mathrm{G} \text { mRNA in the } \\
\mathrm{CD} 4^{+} \mathrm{CCR} 5^{+} \text {blood and } \\
\text { lymph node } \mathrm{T} \text { cells }\end{array}$ \\
\hline
\end{tabular}

$A b$ antibody; $A D C V I$ antibody-dependent cell-mediated viral inhibition; Env envelope; Gag group-specific antigen; HSP heat shock protein; $I D$ intradermal; $I L$ interleukin; IM intramuscular; IN intranasal; IR intrarectal; IT intratracheal; IVAG intravaginal; $M P L-S E$ monophosphoril lipid A stable emulsion; $M U L V$ Moloney murine leukemia virus; $M V A$ modified vaccinia virus Ankara; $N e f$ negative factor; $S C I V$ single-cycle viral vectors; $S F$ San Francisco; SHIV simian-human immunodeficiency virus; SIV simian immunodeficiency virus; $v R N A$ viral RNA

${ }^{a}$ Does not include live-attenuated virus studies

the intradermal route in three, by the subcutaneous (subQ) route in two, and by the transdermal route in one (Table 2).

Among the 21 articles reviewed, the vaccinated animals were challenged by intrarectal (IR) inoculation in 15 articles, by intravaginal (IVAG) inoculation in three, by tonsil inoculation in two, and by oral virus inoculation in one (Tables 1 and 2). Of the 12 articles utilizing mucosal immunization routes, complete protection from, or increased resistance to, infection was reported in three articles [24-26] (Table 1). This includes two articles reporting protection from IR challenge with highly pathogenic SIVmac239 and one from IVAG challenge with variably pathogenic SHIV162P4. The animals in these three articles were immunized with various viral antigens, but all three 
vaccines included the viral envelope. However, there was no commonality in the immunization routes in these three studies, as either rectal, IN, or tonsillar immunization routes were used. In two of these three articles, the route of immunization and challenge was matched [24, 25]. Although many of the other mucosally administered vaccines decreased viral replication after immunized animals became infected, none could block infection (Table 1).

Of the nine articles utilizing systemic immunization routes, complete protection from, or increased resistance to, infection was reported in one article (Table 2). This article reported increased resistance to IR challenge with a highly pathogenic SIVmac239 and used subQ immunization with a replication competent cytomegalovirus (CMV) vector expressing multiple SIV antigens, including envelope. Although the vaccine increased resistance to rectal SIV challenge, virus replication in immunized animals that became infected was not altered [27]. The immunologic basis for the all-or-none protection phenomena seen in this study remains to be defined, but the results are similar to the all-or-none protection seen in both recently completed human AIDS vaccine efficacy trials $[1-3,4 \bullet \bullet]$. Although the CMV vector was systemically administered, it is a replicating viral vector that disseminates throughout the body and produces antigen continuously, albeit at a low level, in mucosal tissues. Thus, it may not be surprising that the only study reporting protection from mucosal challenge after systemic immunization used a replicating viral vector as a vaccine [27]. Although many of the other systemically administered vaccines decreased viral replication after immunized animals became infected, none could block infection (Table 2).

\section{Lessons from Live-Attenuated AIDS Vaccine Models}

We recently completed a series of studies that defined antiviral T-cell responses in the mucosal and systemic

Table 2 Summary of recent (2007-2009) prophylactic AIDS vaccine studies employing systemic immunization and mucosal virus challenge in NHP models ${ }^{\mathrm{a}}$

\begin{tabular}{|c|c|c|c|c|c|}
\hline Study & Vaccine & $\begin{array}{l}\text { Vaccine } \\
\text { route }\end{array}$ & $\begin{array}{l}\text { Challenge/ } \\
\text { route }\end{array}$ & Level of protection & Immune correlates \\
\hline $\begin{array}{l}\text { Beignon } \\
\text { et al. [43] }\end{array}$ & $\begin{array}{l}\text { Lentiviral vector: TRIP- } \\
\text { SIVmac239 gag }\end{array}$ & subQ & $\begin{array}{l}\text { SIVmac251/ } \\
\text { IR }\end{array}$ & Reduction of acute viremia & T-cell responses in PBMC \\
\hline $\begin{array}{l}\text { Zhao et al. } \\
\text { [44] }\end{array}$ & $\begin{array}{l}\text { DNA/MVA HIV-1 } \\
\text { immunogens }\end{array}$ & $\mathrm{IM}$ & $\begin{array}{l}\text { SHIV162P/ } \\
\text { IR }\end{array}$ & $\begin{array}{l}\text { Lower peak and total plasma } \\
\text { vRNA levels }\end{array}$ & $\begin{array}{l}\text { Non-neutralizing but high-avidity } \\
\mathrm{Ab} \text { in plasma }\end{array}$ \\
\hline $\begin{array}{l}\text { Suh et al. } \\
{[45]}\end{array}$ & $\begin{array}{l}\text { Multigenic DNA and } \\
\text { recombinant adenovirus } \\
\text { vaccine }\end{array}$ & IM & $\begin{array}{l}\text { SIVmac239/ } \\
\text { oral }\end{array}$ & $\begin{array}{l}\text { Lower plasma vRNA levels; } \\
\text { prolonged survival }\end{array}$ & $\begin{array}{l}\text { Gag-specific IFN- } \gamma \text { ELISPOT } \\
\text { T-cell responses in PBMC }\end{array}$ \\
\hline $\begin{array}{l}\text { Sparger } \\
\text { et al. [46] }\end{array}$ & $\begin{array}{l}\Delta v i f \text { SIVmac239 DNA } \\
\text { vaccine boosted with } \\
\text { SIV/CMV } \Delta \text { vif } \\
\text { plasmid DNA }\end{array}$ & IM & $\begin{array}{l}\text { SIVmac251/ } \\
\text { vaginal }\end{array}$ & $\begin{array}{l}\text { Transient decrease in plasma } \\
\text { vRNA levels; prolonged } \\
\text { survival }\end{array}$ & $\begin{array}{l}\text { SIV-specific T-cell proliferative } \\
\text { responses and antiviral antibody } \\
\text { titers in blood }\end{array}$ \\
\hline $\begin{array}{l}\text { Dubie et al. } \\
\text { [47] }\end{array}$ & $\begin{array}{l}\text { SIV/CMV } \Delta \text { vif } \text { DNA }+ \\
\text { (rIL)-15 expression plasmid }\end{array}$ & $\mathrm{IM} / \mathrm{ID}$ & $\begin{array}{l}\text { SIVmac251/ } \\
\text { vaginal }\end{array}$ & $\begin{array}{l}\text { Sustained suppression of } \\
\text { plasma virus loads }\end{array}$ & $\begin{array}{l}\text { SIV-specific cellular responses } \\
\text { greater in blood at } 12 \text {-wk PC }\end{array}$ \\
\hline $\begin{array}{l}\text { Lai et al. } \\
{[48]}\end{array}$ & DNA/MVA + GM-CSF & IM or ID & $\begin{array}{l}\text { SHIV89.6P/ } \\
\text { IR }\end{array}$ & $\begin{array}{l}\text { Lower peak viremia and } \\
\text { virus shedding }\end{array}$ & $\begin{array}{l}\text { High avidity anti-Env IgG in } \\
\text { blood and long-lasting antiviral } \\
\text { IgA in rectal secretions }\end{array}$ \\
\hline $\begin{array}{l}\text { Cristillo } \\
\text { et al. [49] }\end{array}$ & $\begin{array}{l}\text { DNA boosted with HIV-1 } \\
\text { gp120 Env and p41 }\end{array}$ & Transdermal & $\begin{array}{l}\text { SHIV162P3/ } \\
\text { IR }\end{array}$ & $\begin{array}{l}\text { Lower plasma viremia } \\
\text { ( } 4 / 5 \text { animals })\end{array}$ & $\begin{array}{l}\text { Gag- and Env-specific central } \\
\text { memory T-cell responses on } \\
\text { the day of challenge }\end{array}$ \\
\hline $\begin{array}{l}\text { Hansen } \\
\text { et al. [27] }\end{array}$ & $\begin{array}{l}\text { RhCMV vectors expressing } \\
\text { SIV Gag, Rev/Nef/Tat, } \\
\text { and Env }\end{array}$ & subQ & $\begin{array}{l}\text { SIVmac239/ } \\
\text { IR }\end{array}$ & $\begin{array}{l}\text { Increased resistance to } \\
\text { infection }\end{array}$ & $\begin{array}{l}\text { SIV-specific, } \mathrm{T}_{\mathrm{EM}} \text { responses } \\
\text { and accumulation in lung }\end{array}$ \\
\hline $\begin{array}{l}\text { Vaccari } \\
\text { et al. [50] }\end{array}$ & $\begin{array}{l}\text { DNA-poxvirus-based } \\
\text { vaccines }\end{array}$ & $\mathrm{IM}+\mathrm{ID} / \mathrm{IM}$ & $\begin{array}{l}\text { SIVmac251/ } \\
\text { IR }\end{array}$ & $\begin{array}{l}\text { Lower vRNA levels in } \\
\text { mucosal sites; preservation } \\
\text { of mucosal CD4 } 4^{+} \mathrm{CRR}^{+} \\
\mathrm{T} \text { cells }\end{array}$ & $\begin{array}{l}\text { Delayed or no expression of } \\
\text { T-cell activation markers in } \\
\text { mucosal sites }\end{array}$ \\
\hline
\end{tabular}

$A b$ antibody; CMV cytomegalovirus; ELISPOT enzyme-linked immunosorbent spot; Env envelope; Gag group-specific antigen; GMCSF granulocyte-macrophage colony-stimulating factor; ID intradermal; $I F N$ interferon; $I M$ intramuscular; $I R$ intrarectal; $M V A$ modified vaccinia virus Ankara; Nef negative factor; $P B M C$ peripheral blood mononuclear cell; $P C$ postchallenge; Rev regulator of virion protein expression; $R h C M V$ rhesus cytomegalovirus; $r I L$ recombinant interleukin; SHIV simian-human immunodeficiency virus; SIV simian immunodeficiency virus; $s u b Q$ subcutaneous; Tat trans-activator of tTranscription; $T_{E M}$ effector memory T cells; TRIP triplicate

${ }^{a}$ Does not include live-attenuated virus studies 
tissues of SHIV-immunized rhesus macaques before and after vaginal SIV challenge. The results of these studies demonstrated that SIV Gag-specific $\mathrm{CD}^{+} \mathrm{T}$ cells in the vaginal mucosa at the time of SIV challenge are the key immune effector function mediating protection in this model [10, 28-30], and that $\mathrm{CD}^{+}$lymphocyte depletion leaves SHIV-immunized animals completely unprotected from the vaginal SIV challenge [10, 29]. Despite the evidence for the critical role of SIV-specific $\mathrm{CD}^{+}$T-cell responses in SHIV-immunized monkeys, expansion of SIVspecific $\mathrm{CD} 8^{+} \mathrm{T}$ cells is limited to the vaginal mucosa, and there is minimal immune activation after the SIV challenge [29]. The extent of host inflammation and immune activation affects viral transcription directly and determines the number of target cells available for virus replication. HIV and SIV replication are regulated by a complex

\section{Immunized animals}

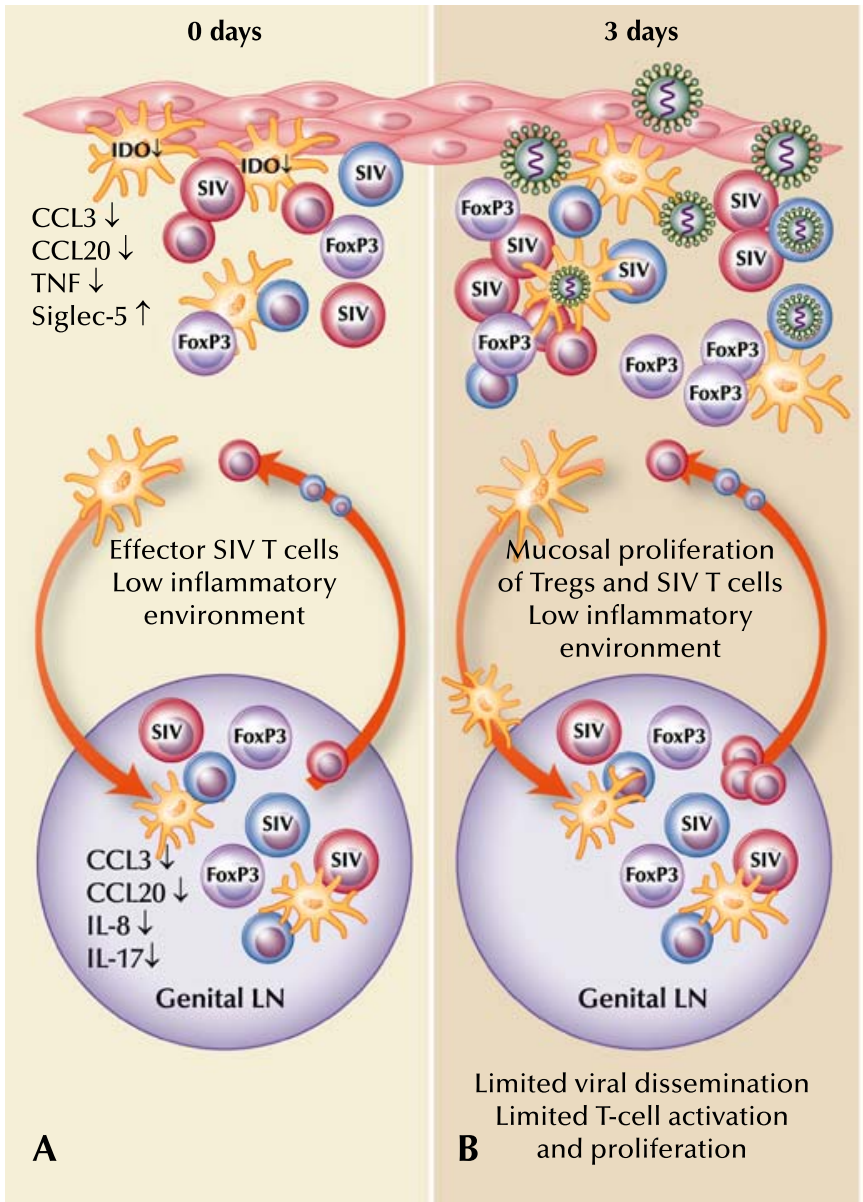

Fig. 1 Innate and adaptive immune responses in the vagina at the time of, and immediately after, vaginal SIV inoculation of rhesus macaques immunized with an attenuated lentivirus compared with the responses in nonimmunized rhesus macaques. The figure schematically depicts the vaginal mucosa and the draining lymph node of SHIV89.6-immunized RMs (a, b) and nonimmunized RMs (c, d) at day $0(\mathbf{a}, \mathbf{c})$ and day $3(\mathbf{b}, \mathbf{d})$ after SIVmac239 vaginal challenge. In all panels, nonspecific $\mathrm{T}$ cells are gray to black. a SIV-specific $\mathrm{CD}^{+} \mathrm{T}$ cells (blue circles) and $\mathrm{CD}^{+} \mathrm{T}$ cells (red circles) are present on the vaginal mucosa of immunized RMs on the day of SIV challenge. The number of $\mathrm{IDO}^{+}$APCs (orange) are reduced, and the mRNA levels of proinflammatory cytokines (C-C motif chemokine 3 [CCL3], CCL20, and TNF) are reduced, while the mRNA levels of the immunoregulatory Siglec- 5 molecule are increased. In the genital lymph node, expression of CCL3, CCL20, IL-8, and IL-17 are also downregulated. b Three days after challenge, SIV infection is limited to the mucosal site of challenge in immunized animals. This early containment is

\section{Nonimmunized animals}

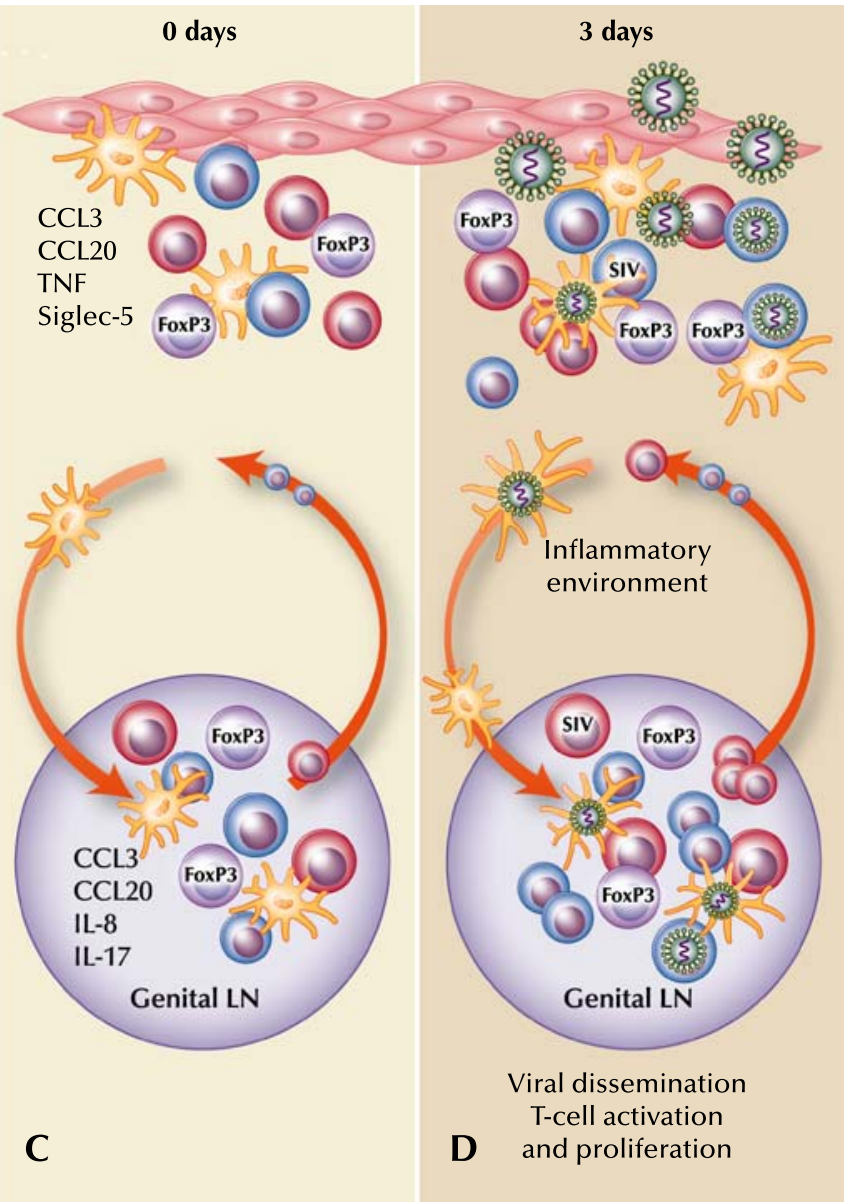

associated with the presence of SIV-specific effector $\mathrm{CD} 8^{+} \mathrm{T}$ cells in the vaginal mucosa and the proliferation of regulatory $\mathrm{FOXP} 3^{+} \mathrm{CD} 4^{+}$ $\mathrm{T}$ cells (purple circles) in the mucosa. $\mathbf{c}$ In contrast, in nonimmunized RMs there are no SIV-specific memory effector T cells in the mucosa, and the levels of proinflammatory or regulatory $\mathrm{T}$ cells are normal on the day of challenge. d However, after the virus enters the mucosa, local viral replication leads to systemic dissemination, and the level of infection rapidly exceeds the ability of the immune system to contain viral replication. The pace of SIV replication accelerates over the first 2 to 5 days of infection, as the rapid increase in local and systemic proinflammatory cytokines recruits and activates viral target cells in the vaginal mucosa. APC antigen-presenting cell; FOXP3 forkhead box P3; IDO indoleamine 2,3-dioxygenase; $I L$ interleukin; $L N$ lymph node; $R M$ rhesus macaque; $S H I V$ simian-human immunodeficiency virus; Siglec sialic acid-binding immunoglobulin-like lectin; SIV simian immunodeficiency virus; TNF tumor necrosis factor 
network of cytokines and chemokines, as these soluble factors directly influence reverse transcription, HIV RNA expression, and expression of viral receptors and coreceptors [31-33]. Cytokine and chemokines also regulate migration and activation of viral target cells, amplifying HIV infection and replication [31-33]. Thus, both the strength of the $\mathrm{CD}^{+}$T-cell response and the degree of immune activation and inflammation can influence the level of viral replication. After vaginal SIV challenge, immune activation in the SHIV-immunized animals was controlled and limited, in contrast to the aberrant T-cell activation in the unimmunized animals [29]. On the day of SIV challenge, the antiviral $\mathrm{CD}^{+}{ }^{+}$-cell responses of SHIV-immunized animals existed in a relatively quiescent tissue environment [28] (Fig. 1). After SIV challenge, this quiescent tissue environment was actively maintained by a T-regulatory cell response that rapidly expanded to suppress any immune activation and prevent the generation of more activated target cells to support SIV replication (Genescà and Miller, unpublished data) (Fig. 1). The decreased levels of proinflammatory cytokines and indoleamine 2,3-dioxygenase $\left(\mathrm{IDO}^{+}\right)$cells in SHIV-immunized animals after vaginal SIV challenge are consistent with immunoregulatory mechanisms playing an active role in achieving this condition (Genescà and Miller, unpublished data) (Fig. 1).

\section{Conclusions}

The goal of conventional HIV vaccines is to elicit a strong systemic neutralizing antibody response that can limit infection upon HIV exposure and $\mathrm{CD}^{+}$T-cell responses to clear the infection after transmission. To improve the efficacy of these vaccines against mucosally transmitted HIV infections, new strategies for directing immune responses into mucosal sites are needed. Further, as immune activation and T-cell expansion counter balance the benefits of strong antiviral mucosal immune responses (Genescà and Miller, unpublished data), understanding and controlling the relationship between immune activation and protective mucosal immune responses may be a critical factor in developing an effective mucosal AIDS vaccine. An effective vaccine against HIV will require broadly neutralizing antibody responses to block infection of new target cells and antiviral $\mathrm{T}$ cells to control viral spread and eliminate infected cells. However, the results of efficacy trials of systemic AIDS vaccines suggest that antiviral immune responses at mucosal surfaces will be required to increase protection levels in AIDS vaccines. New immunization routes and adjuvants that can boost antiviral immunity in mucosal surfaces offer the best hope for improving AIDS vaccine efficacy in the near term, and NHP models offer the best system for preclinical evaluation of these approaches.
Acknowledgments This work was supported by Public Health Service grants U51RR00169 from the National Center for Research Resources and P01 AI055793 from the National Institute of Allergy and Infectious Diseases and a gift from the James B. Pendleton Charitable Trust.

Disclosure No potential conflicts of interest relevant to this article were reported.

Open Access This article is distributed under the terms of the Creative Commons Attribution Noncommercial License which permits any noncommercial use, distribution, and reproduction in any medium, provided the original author(s) and source are credited.

\section{References}

Papers of particular interest, published recently, have been highlighted as:

- Of importance

•• Of major importance

1. Steinbrook R: One step forward, two steps back: will there ever be an AIDS vaccine? N Engl J Med 2007, 357:26532655.

2. Walker BD, Burton DR: Toward an AIDS vaccine. Science 2008, 320:760-764.

3. Haynes BF, Shattock RJ: Critical issues in mucosal immunity for HIV-1 vaccine development. J Allergy Clin Immunol 2008, 122:3-9.

4. •- Rerks-Ngarm S, Pitisuttithum P, Nitayaphan S, et al.: Vaccination with ALVAC and AIDSVAX to prevent HIV-1 infection in Thailand. N Engl J Med 2009 Nov 19 (Epub ahead of print). This article reports the results of the recently completed RV144 phase $3 \mathrm{HIV}$ vaccine trial demonstrating that ALVACbased HIV vaccines can protect some people from acquiring $H I V$ infection. This result was predicted by preclinical testing of ALVAC-based vaccines in NHP mucosal challenge models [21].

5. Brandtzaeg P, Kiyono H, Pabst R, et al.: Terminology: nomenclature of mucosa-associated lymphoid tissue. Mucosal Immunol 2008, 1:31-37.

6. Holmgren J, Czerkinsky C: Mucosal immunity and vaccines. Nat Med 2005, 11:S45-S53.

7. McGhee JR, Xu-Amano J, Miller CJ, et al.: The common mucosal immune system: from basic principles to enteric vaccines with relevance for the female reproductive tract. Reprod Fertil Dev 1994, 6:369-379.

8. Hladik F, McElrath MJ: Setting the stage: host invasion by HIV. Nat Rev Immunol 2008, 8:447-457.

9. Miller CJ, Li Q, Abel K, et al.: Propagation and dissemination of infection after vaginal transmission of simian immunodeficiency virus. J Virol 2005, 79:9217-9227.

10. Stone $M$, Ma ZM, Genescà $M$, et al.: Limited dissemination of pathogenic SIV after vaginal challenge of rhesus monkeys immunized with a live, attenuated lentivirus. Virology 2009, 392:260-270 
11. Hu J, Gardner MB, Miller CJ: Simian immunodeficiency virus rapidly penetrates the cervicovaginal mucosa after intravaginal inoculation and infects intraepithelial dendritic cells. J Virol 2000, 74:6087-6095.

12. Abel K, Rocke DM, Chohan B, et al.: Temporal and anatomic relationship between virus replication and cytokine gene expression after vaginal simian immunodeficiency virus infection. J Virol 2005, 79:12164-12172.

13. Keele BF, Giorgi EE, Salazar-Gonzalez JF, et al.: Identification and characterization of transmitted and early founder virus envelopes in primary HIV-1 infection. Proc Natl Acad Sci U S A 2008, 105:7552-7557.

14. - Keele BF, Li H, Learn GH, et al.: Low-dose rectal inoculation of rhesus macaques by SIVsmE660 or SIVmac251 recapitulates human mucosal infection by HIV-1. J Exp Med 2009, 206:11171134. This article identifies key similarities in mucosal transmission and early diversification after mucosal SIV and HIV-1 transmission, validating the biological relevance of the SIVmacaque mucosal transmission model for HIV-1 vaccine and microbicide research.

15. Ma ZM, Stone M, Piatak M Jr, et al.: High specific infectivity of plasma virus from the pre-ramp-up and ramp-up stages of acute simian immunodeficiency virus infection. J Virol 2009, 83:32883297.

16. Hessell AJ, Poignard P, Hunter M, et al.: Effective, low-titer antibody protection against low-dose repeated mucosal SHIV challenge in macaques. Nat Med 2009, 15:951-954.

17. Melkus MW, Estes JD, Padgett-Thomas A, et al.: Humanized mice mount specific adaptive and innate immune responses to EBV and TSST-1. Nat Med 2006, 12:1316-1322.

18. Denton PW, Estes JD, Sun Z, et al.: Antiretroviral pre-exposure prophylaxis prevents vaginal transmission of HIV-1 in humanized BLT mice. PLoS Med 2008, 5:e16.

19. Brainard DM, Seung E, Frahm N, et al.: Induction of robust cellular and humoral virus-specific adaptive immune responses in human immunodeficiency virus-infected humanized BLT mice. J Virol 2009, 83:7305-7321.

20. Morgan C, Marthas M, Miller C, et al.: The use of nonhuman primate models in HIV vaccine development. PLoS Med 2008, 5: e173.

21. Van Rompay KK, Abel K, Lawson JR, et al.: Attenuated poxvirus-based simian immunodeficiency virus (SIV) vaccines given in infancy partially protect infant and juvenile macaques against repeated oral challenge with virulent SIV. J Acquir Immune Defic Syndr 2005, 38:124-134.

22. Yoshino N, Lu FX, Fujihashi K, et al.: A novel adjuvant for mucosal immunity to HIV-1 gp120 in nonhuman primates. J Immunol 2004, 173:6850-6857.

23. - Demberg T, Robert-Guroff M: Mucosal immunity and protection against HIV/SIV infection: strategies and challenges for vaccine design. Int Rev Immunol 2009, 28:20-48. This article includes an extensive review of the mucosal transmission of HIV, the challenges of mucosal immunology, and a detailed summary of the current (2004-2009) approaches to create mucosal immune responses with HIV vaccines.

24. Wang Y, Bergmeier LA, Stebbings R, et al.: Mucosal immunization in macaques upregulates the innate APOBEC $3 \mathrm{G}$ anti-viral factor in CD4(+) memory T cells. Vaccine 2009, 27:870-881.

25. Vagenas P, Williams VG, Piatak M Jr, et al.: Tonsillar application of AT-2 SIV affords partial protection against rectal challenge with SIVmac239. J Acquir Immune Defic Syndr 2009, 52:433-442.

26. Barnett SW, Srivastava IK, Kan E, et al.: Protection of macaques against vaginal SHIV challenge by systemic or mucosal and systemic vaccinations with HIV-envelope. AIDS 2008, 22:339348 .
27. Hansen SG, Vieville C, Whizin N, et al.: Effector memory T cell responses are associated with protection of rhesus monkeys from mucosal simian immunodeficiency virus challenge. Nat Med 2009, 15:293-299.

28. Genescà $\mathrm{M}$, Skinner PJ, Bost $\mathrm{K}$, et al.: Protective attenuated lentivirus immunization induces SIV-specific T cells in the genital tract of rhesus monkeys. Mucosal Immunol 2008, 1:219-228.

29. Genescà $M$, Skinner PJ, Hong JJ, et al.: With minimal systemic Tcell expansion, CD8+ T cells mediate protection of rhesus macaques immunized with attenuated simian-human immunodeficiency virus SHIV89.6 from vaginal challenge with simian immunodeficiency virus. J Virol 2008, 82: 11181-11196.

30. Genescà M, McChesney MB, Miller CJ: Antiviral CD8+ T cells in the genital tract control viral replication and delay progression to AIDS after vaginal SIV challenge in rhesus macaques immunized with virulence attenuated SHIV 89.6. J Intern Med 2009, 265:67-77.

31. Yoshie O: Role of chemokines in trafficking of lymphocytes and dendritic cells. Int J Hematol 2000, 72:399-407.

32. Kedzierska K, Crowe SM, Turville S, et al.: The influence of cytokines, chemokines and their receptors on HIV-1 replication in monocytes and macrophages. Rev Med Virol 2003, 13:39-56.

33. Copeland KF: Modulation of HIV-1 transcription by cytokines and chemokines. Mini Rev Med Chem 2005, 5:1093-1101.

34. Manrique M, Kozlowski P, Wang SW, et al.: Nasal DNA-MVA SIV vaccination provides more significant protection from progression to AIDS than a similar intramuscular vaccination. Mucosal Immunol 2009, 2:536-550.

35. Manrique M, Micewicz E, Kozlowski PA, et al.: DNA-MVA vaccine protection after X4 SHIV challenge in macaques correlates with day-of-challenge antiviral CD4+ cell-mediated immunity levels and postchallenge preservation of CD4+ T cell memory. AIDS Res Hum Retroviruses 2008, 24:505-519.

36. Falkensammer B, Rubner B, Hiltgartner A, et al.: Role of complement and antibodies in controlling infection with pathogenic simian immunodeficiency virus (SIV) in macaques vaccinated with replication-deficient viral vectors. Retrovirology 2009, 6:60.

37. Stahl-Hennig C, Eisenblatter M, Franz M, et al.: A single vaccination with attenuated SIVmac 239 via the tonsillar route confers partial protection against challenge with SIVmac 251 at a distant mucosal site, the rectum. Front Biosci 2007, 12:21072123.

38. Bogers WM, Davis D, Baak I, et al.: Systemic neutralizing antibodies induced by long interval mucosally primed systemically boosted immunization correlate with protection from mucosal SHIV challenge. Virology 2008, 382:217-225.

39. Hidajat R, Xiao P, Zhou Q, et al.: Correlation of vaccine-elicited systemic and mucosal nonneutralizing antibody activities with reduced acute viremia following intrarectal simian immunodeficiency virus SIVmac251 challenge of rhesus macaques. J Virol 2009, 83:791-801.

40. Demberg T, Boyer JD, Malkevich N, et al.: Sequential priming with simian immunodeficiency virus (SIV) DNA vaccines, with or without encoded cytokines, and a replicating adenovirus-SIV recombinant followed by protein boosting does not control a pathogenic SIVmac251 mucosal challenge. J Virol 2008, 82:10911-10921.

41. Zhou Q, Hidajat R, Peng B, et al.: Comparative evaluation of oral and intranasal priming with replication-competent adenovirus 5 host range mutant (Ad5hr)-simian immunodeficiency virus (SIV) recombinant vaccines on immunogenicity and protective efficacy against SIV(mac251). Vaccine 2007, 25:8021-8035.

42. Stolte-Leeb N, Bieler K, Kostler J, et al.: Better protective effects in rhesus macaques by combining systemic and mucosal application of a dual component vector vaccine after rectal SHIV89.6P 
challenge compared to systemic vaccination alone. Viral Immunol 2008, 21:235-246.

43. Beignon AS, Mollier K, Liard C, et al.: Lentiviral vector-based prime/boost vaccination against AIDS: pilot study shows protection against Simian immunodeficiency virus SIVmac251 challenge in macaques. J Virol 2009, 83:10963-10974.

44. Zhao J, Lai L, Amara RR, et al.: Preclinical studies of human immunodeficiency virus/AIDS vaccines: inverse correlation between avidity of anti-Env antibodies and peak postchallenge viremia. J Virol 2009, 83:4102-4111.

45. Suh YS, Park KS, Sauermann U, et al.: Prolonged survival of vaccinated macaques after oral SIVmac239 challenge regardless of viremia control in the chronic phase. Vaccine 2008, 26:66906698.

46. Sparger EE, Dubie RA, Shacklett BL, et al.: Vaccination of rhesus macaques with a vif-deleted simian immunodeficiency virus proviral DNA vaccine. Virology 2008, 374:261-272.
47. Dubie RA, Maksaereekul S, Shacklett BL, et al.: Co-immunization with IL-15 enhances cellular immune responses induced by a vif-deleted simian immunodeficiency virus proviral DNA vaccine and confers partial protection against vaginal challenge with SIVmac251. Virology 2009, 386:109-121.

48. Lai L, Vodros D, Kozlowski PA, et al.: GM-CSF DNA: an adjuvant for higher avidity $\operatorname{IgG}$, rectal $\mathrm{IgA}$, and increased protection against the acute phase of a SHIV-89.6P challenge by a DNA/MVA immunodeficiency virus vaccine. Virology 2007, 369:153-167.

49. Cristillo AD, Lisziewicz J, He L, et al.: HIV-1 prophylactic vaccine comprised of topical DermaVir prime and protein boost elicits cellular immune responses and controls pathogenic R5 SHIV162P3. Virology 2007, 366:197-211.

50. Vaccari M, Boasso A, Ma ZM, et al.: CD4+ T-cell loss and delayed expression of modulators of immune responses at mucosal sites of vaccinated macaques following SIV(mac251) infection. Mucosal Immunol 2008, 1:497-507. 